\title{
位相差顕微鏡法による加熱クリソタイルの評価
}

\author{
橋本＼cjkstart忍·奥田篤史 $*$ ·上林 晃·本多沢雄 $\cdot$ 淡路英夫 ·福田功一郎 \\ 名古屋工業大学環境材料工学科, 466-8555 名古屋市昭和区御器所町 \\ *(株)富士清空工業所, 500-8474 岐阜市加納本町 6-18
}

\section{Evaluation of Heated Chrysotile Using Phase-Contrast Microscope}

\author{
Shinobu HASHIMOTO, Atsushi OKUDA, * Akira KANBAYASHI, Sawao HONDA, \\ Hideo AWAJI and Koichiro FUKUDA
}

Department of Invironmental and Materials Engineering, Nagoya Institute of Technology, Gokiso-cho, Showa-ku, Nagoya-shi 466-8555 *Fuji Seiku Kogyosho Corporation, Ltd., 6-18, Kanou Honmachi, Gifu-shi 500-8474

\begin{abstract}
According to XED analysis, the chrysotile changed to an amorphous phase after heating at $600^{\circ} \mathrm{C}$ for $3 \mathrm{~h}$. With heating at temperatures exceeding $700^{\circ} \mathrm{C}$, chrysotile changed to forsterite. After heating at $1000^{\circ} \mathrm{C}$ for $3 \mathrm{~h}$, observation by phase-contrast microscopy revealed that only a very small number of chrysotile particles remained in the sample. In contrast, treating of the JIS A 1481: 2006 sample under the same conditions $\left(1000^{\circ} \mathrm{C}, 3 \mathrm{~h}\right)$ resulted in the complete disappearance of chrysotile particles. [Received June 1, 2006; Accepted July 20, 2006]
\end{abstract}

Key-words : Asbestos, Chrysotile, Heat treatment, Detoxification technique, Phase-contrast microscope

\section{1. 緒 言}

蛇紋石族系アスベストのクリソタイルは，1970年代の世界の アスベスト生産の最盛期に，世界生産量の実に $95 \%$ を占めてい た ${ }^{1)}$ 。た，日本では角閃石族系のクロシドライトとアモイサ イトは1995年に使用が禁止された。それゆえアスベストといえ ばクリソタイルのことを指し，アスベスト廃棄物の無害化はク リソタイルを中心に考えればよい。

現在，環境省を中心とする国のアスベスト廃棄物の処理技術 の方針は溶融法に定まりつつある。クリソタイル単体の融点は $1521^{\circ} \mathrm{C}^{2)}$ と高いが，塩化ナトリウムなどの塩と同時に加熱する 低温融解処理技術3) が研究されている. 他にも都市ゴミ4), ア ルミニウム精錬灰 ${ }^{5)}$ ，ケイ酸カリウムやケイ酸ソーダ6)などと 混ぜ合わせて，クリソタイルの融点より低い温度で加熱し，他 の割業製品を作製するなど処理後の有効活用なで考えた研究も 進められている。しかしながら，これら溶融法を中心とする無 害化技術は高いエネルギーコスト，共融物の恒常的確保の問題 (都市ゴミなどでは組成の不安定性), セメントなど共存物から の二酸化炭素の排出, 処理設備の用地確保, またその設備の経 費負担などの諸問題が残る.

著者らはクリソタイルを無害化する一技術として，600ํㅡ 上で加熱しその後粉砕する方法を提案した. クリソタイルは $600^{\circ} \mathrm{C}$ の温度で脱水して非晶質化し，更に高温ではフォルステ ライトが析出する（ノンアスベスト化する） ${ }^{7)}$ が，その場合同時 に脆くなるので, Stanton ${ }^{8)}$ や Pott ${ }^{9)}$ らの提唱した人体に危険な サイズより容易に小さく粉砕でき, その粉砕処理までされた粒 子は人体組織に刺さりにくく, 無害である可能性が高い, と考 えた。しかし JIS 規格（JIS A 1481: 2006）には，アスペクト 比（繊維の長さ/径）が「3」以上の粒子をアスベスト繊維とし て数えるという規定があり, 粒子の数を粉砕で増やす処理技術 は適切でないという見方もある。

現在，JIS 規格（JIS A 1481: 2006）で定めるクリソタイル の含有の有無を決定する方法は，位相差顕微鏡を使った分散染 色法と, 粉末 X 線回折法（XRD）の併用によるものである. クリソタイルは $600^{\circ} \mathrm{C}$ 以上の加熱で脱水し, 結晶構造としては
クリソタイルでなくなる7)が，その場合のクリソタイル繊維の 一本一本の結晶状態の変化まで詳しく位相差顕微鏡を使って評 価したデータは見当たらない。

本研究は, 通常アスベストの検出のために行われている位相 差顕微鏡法を加熱したクリソタイルに適用し，上記 JIS 規格で 定める位相差顕微鏡法による判定基準で「クリソタイルは含有 されない」，つまり「ノンアスベスト」とできる加熱処理条件 の確立を目的とした.

\section{2. 実験方法}

実験用アスベストとして，カナダケベック州産のクリソタイ ルを用いた。 その化学組成などの詳細は既報に記した ${ }^{7)}$ 。その クリソタイル $3 \mathrm{~g}$ をアルミナるつぼ（径60 mm，高さ $75 \mathrm{~mm}$ ） に入れ，電気炉にて加熱した．加熱速度は $10^{\circ} \mathrm{C} / \mathrm{min}$ とし， 600 ${ }^{\circ} \mathrm{C}$ から $1100^{\circ} \mathrm{C}$ 各温度で $3 \mathrm{~h}$ 加熱した. 加熱保持後, 電気师の 電源を切り, アルミナるつぼ中の試料は室温まで自然冷却させ た. 加熱処理された試料の結晶相変化を粉末 X 線回折分析 （XRD）装置により分析した.

次に位相差顕微鏡法によるクリソタイルの判定実験を行っ た。本実験では通常の JIS 法による評価のほかに，クリソタイ ルの性質をより詳しく調べる目的から，JIS 法では行う粉砕と ふるい分け処理を行わず，加熱した試料を直接評価する（この 方法を本実験では「直接分析法」と呼ぶ）方法も採用した。こ の位相差顕微鏡によるクリソタイルの直接分析法と JIS 法につ いて以下に詳しく記す.

\section{直接分析法}

清拭したスライドガラスに蒸留水 $30 \mu \mathrm{L}$ を滴下し, 各温度で 加熱された試料をピンセットで適量載せた。ピンセットの先で 試料を分散させた後, 低温のホットプレート上にそのスライド ガラスを置き, 十分に乾燥させた. Gargille 製, 屈折率 $N_{\mathrm{D}}{ }^{25^{\circ} \mathrm{C}}$ $=1.550$ の浸液を滴下し, 清拭したカバーガラスをかけた。こ の標本を位相差顕微鏡による分散染色法で観察した。本来クリ ソタイルはこの方法により青から赤紫色に呈色することが分 かっている. 始めに未加熱クリソタイルを観察し，その結果と 


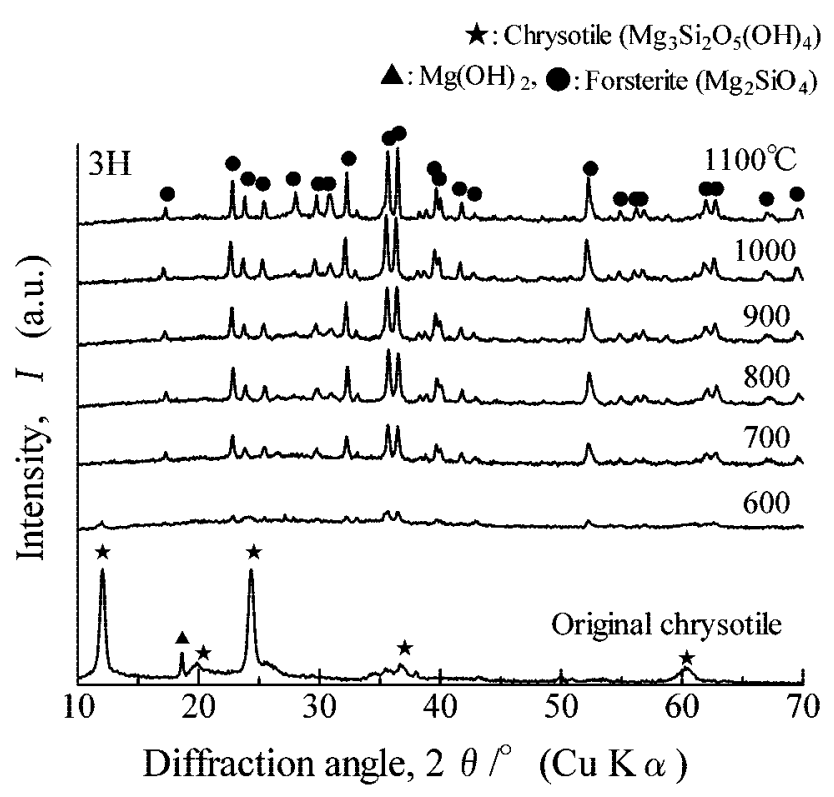

Fig. 1. XRD patterns of chrysotile after heating at $600-1100^{\circ} \mathrm{C}$ for $3 \mathrm{~h}$.

の比較で加熱試料中に残存しているクリソタイルの有無や形状 を観察した。位相差顕微鏡は，Nikon 製，ECLIPSE80i を用い た。

\section{JIS 法による計数法}

JIS A 1481: 2006に準拠して, 各温度で加熱された試料中の クリソタイルの計数を行った. 乳鉢を用いて加熱試料を粉砕し, $425 \mu \mathrm{m}$ のふるいに通した．ふらるいを通過した試料 $20 \mathrm{mg}$ を蒸留 水 $20 \mathrm{~mL}$ に分散させた。十分にかくはんを行いながら，試料が 分散している液 $20 \mu \mathrm{L}$ を採取し，清拭したスライドガラスに滴 下した。 そのスライドガラスを低温のホットプレートに置き十 分に乾燥させた。 Gargille 製, 屈折率 $N_{\mathrm{D}}{ }^{25^{\circ} \mathrm{C}}=1.550$ の浸液を滴 下し, 清拭したカバーガラスをかけ, 位相差顕微鏡による分散 染色法で評価するための計数用標本とした。作製した標本を対 物レンズ40倍, 接眼レンズ10倍を用い, アイピースグレーティ ンクルの直径 $100 \mu \mathrm{m}$ 内にある全粒子と, そのうちの分散色を示 した繊維状粒子「アスペクト比 3 以上」の数を計数し, 全粒子 が1000になるまで計数を続けた．標本は加熱条件毎に 3 枚作製 し, 総合計 3000 粒子として評価を行った，尚，試料をアスベス 卜含有品とする JIS 規格の条件は，3000粒子中繊維状粒子が 4 粒子以上（質量百分率で $0.1 \%$ 以上含めば，アスベスト含有品 とする規定ともとれる）である.

\section{3. 結果と考察}

図 1 に，加熱した試料の XRD 分析結果を示した。比較のた めに未加熱クリソタイルの分析結果も示した. $600^{\circ} \mathrm{C} て ゙$ 加熱し た試料に打いて，クリソタイルと一致するピークはわずかに検 出されたがほとんど消失したといえる. 一方フォルステライト のピークが検出されたものの, そのピーク強度も小さく, この 場合脱水に伴うクリソタイルの非晶質化がほぼ完了したと思わ

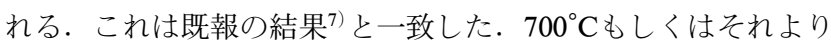
高い温度で加熱した試料では，すべての条件でクリソタイルと 一致する回折線は検出されず，フォルステライトのみが検出さ れた。これはクリソタイルの脱水反応後に非晶質化した試料中 で原子の再配列が起こり, フォルステライトが結晶として析出
したためと考えられる。以上の XRD 分析結果から， $700^{\circ} \mathrm{C}$ 以 上の温度で加熱した場合, クリソタイルの回折線は検出され ず，試料中のクリソタイルは消失した，即ちノンアスベスト化 したといえる.

次に，位相差顕微鏡を用いて加熱試料の評価を直接分析法に より行った。始めに，未加熱クリソタイルを観察した結果を 図 2 に示す. 繊維状粒子はすべて青色に呈色した．この方法に よりクリソタイル繊維状粒子を精度よく検出できることを確認 した. 次に $600^{\circ} \mathrm{C} て ゙$ 加熱した試料は, 多くの繊維状粒子が黄色 味の強い橙色に変化しクリソタイルでなくなったとみられた が，図３に示したように，ところどころに青色を呈する未反応 のクリソタイルとみられる繊維状粒子が観察された。図 19 $600^{\circ} \mathrm{C}$ 試料の XRD 分析からも, わずかのクリソタイルが検 出されていたことと合わせ, $600^{\circ} \mathrm{C}$ の加熱に抢いては, すべて のクリソタイルが消失していないことが明らかとなった。 そこ で，クリソタイルの完全な改質を目的に加熱温度を $400^{\circ} \mathrm{C}$ 上 げ， $1000^{\circ} \mathrm{C}$ で加熱した試料を位相差顕微鏡で評価した. $1000^{\circ} \mathrm{C}$ で加熱するとほとんどの繊維状粒子は橙色に呈色し，それゆえ クリソタイルはほぼ消失したとみられた。これは図1の XRD 分析からも, $700^{\circ} \mathrm{C}$ 上小加熱では, クリソタイルの回折線は 検出されなくなったことと一致した。しかし，この試料をより 一層詳しく観察した場合，極めてわずかではあるが，図４に示 したように，青色を呈するクリソタイルとみられる繊維状粒子 が観察された。ただし, 評価者によってはこの場合クリソタイ ル粒子は未検出と判定しても問題ないほどその数は少なかっ

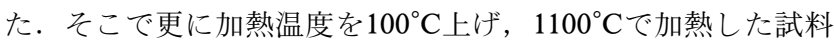
を位相差顕微鏡で評価した. 図 5 に結果の例を示したが，この 加熱条件の場合, 青色に呈色する緎維は全く観察されず，クリ ソタイルは完全に消失したとみられた.

最後に, 通常の判定法であるJIS A 1481: 2006に準拠して, 加熱試料の計数測定を行った.この方法によるアスベスト未検 出という基準が，目下経済産業省の定める「ノンアスベスト」 とできる基準である. 表 1 に $600^{\circ} \mathrm{C}$ から $1100^{\circ} \mathrm{C}$ でクリソタイル を加熱した試料粒子の計数測定を行った結果を示す。各温度で 加熱した試料から作製した標本に対し，総数で3000粒子を計数 した. $600^{\circ} \mathrm{C} て ゙$ 加熱した試料の場合，青色を呈するクリソタイ ルとみられる緘維状粒子が 60 粒子 (2 質量\%に相当) 検出され,

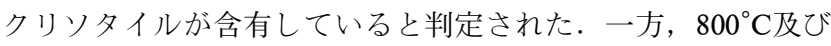
$900^{\circ} \mathrm{C}$ の場合, 3000 粒子中クリソタイルとして検出されたのは わずか 4,5 繊維粒子であったが， 4 粒子以上（0.1質量％以上） の検出をもってアスベスト含有品とする JIS 規格では, アスベ スト含有品という扱いになる. $1000^{\circ} \mathrm{C}$ 以上で加熱した場合, ク リソタイル繊維状粒子は検出されず，アスベストは完全に消失 し，ハンアスベスト化したといえる.

図 4 に示したように，直接分析法による $1000^{\circ} \mathrm{C}$ 試料中には ほんのわずかのクリソタイル繊維粒子が検出された．しかし同 試料の JIS 法による計数によれば，ノンアスベスト品と判定す ることができた。これは，JIS 法では乳鉢による粉砕とふるい 分け処理の操作が入るため, その後の位相差顕微鏡の分散染色 法で検出されるクリソタイル繊維粒子の数が減ったためと考え られる。

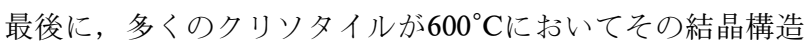
が変化するのに，一部のクリソタイルは $1000^{\circ} \mathrm{C} の$ 高温でも結晶 構造を維持するものがあった理由について考える．本実験では $1000^{\circ} \mathrm{C}$ においても脱水反応を起こさせるまでの熱が試料内部ま で十分に伝わらず，未反応のクリソタイルがわずかに残ったた めと考えられる.しかしながら $1100^{\circ} \mathrm{C} て ゙$ 加熱すると, 試料内部 


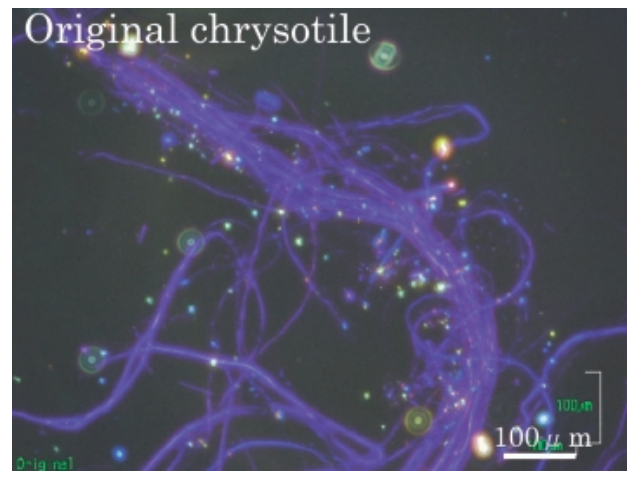

Fig. 2. Phase-contrast microscope photograph of original chrysotile.

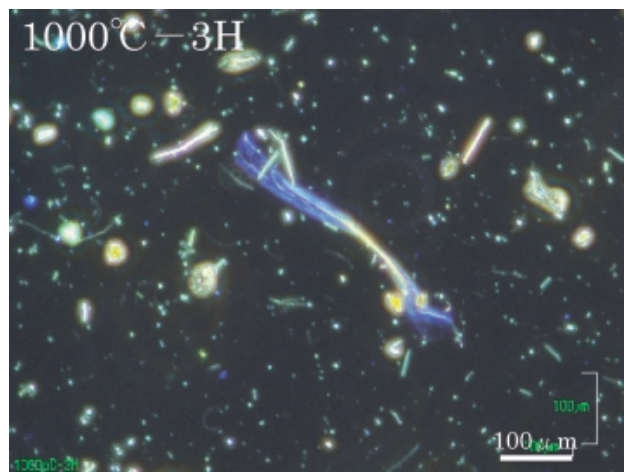

Fig. 4. Phase-contrast microscope photograph of chrysotile after heating at $1000^{\circ} \mathrm{C}$ for $3 \mathrm{~h}$.

にまで反応を起こすのに十分な熱が伝わり，クリソタイルは完 全に消失し, フォルステライトが析出してノンアスベスト化し たものと考えられる.

\section{4. 結 論}

クリソタイルのみを加熱した試料を JIS A 1481: 2006に準拠 する位相差顕微鏡法によって評価し，アスベストは含まれない

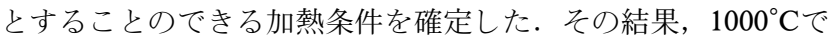
$3 \mathrm{~h}$ 加熱した場合，クリソタイルは完全に消失したと判定でき た.この温度は, XRD 分析よりクリソタイルが消失したと判 定できた $700^{\circ} \mathrm{C} よ り ~ 300^{\circ} \mathrm{C}$ 高かった。

\section{References}

1) Yokoyama, K., "Sekimen · Zeoraito no Subete," Nihon Kankyo Eisei Center (1987) pp. 17-17 [in Japanese].

2) Winson, R. W., "Asbestos," 4th ed., Ed. by Lefond, S. J., Industrial Minerals and Rocks (1975) pp. 384-385.

3) Fujishige, M., Obuchi, H., Sato, R. and Kojima, A., J. Ceram. Soc. Japan, Vol. 114, pp. 355-358 (2006) [in Japanese].

4) Moriyoshi, Y., Urano, T. and Miyaji, H., Kokai-Tokkyo-Koho, Toku Kai Hei9-206726 [in Japanese].

5) Yashima, I. and Ito, A., Kokai-Tokkyo-Koho, Toku Kai Hei6-

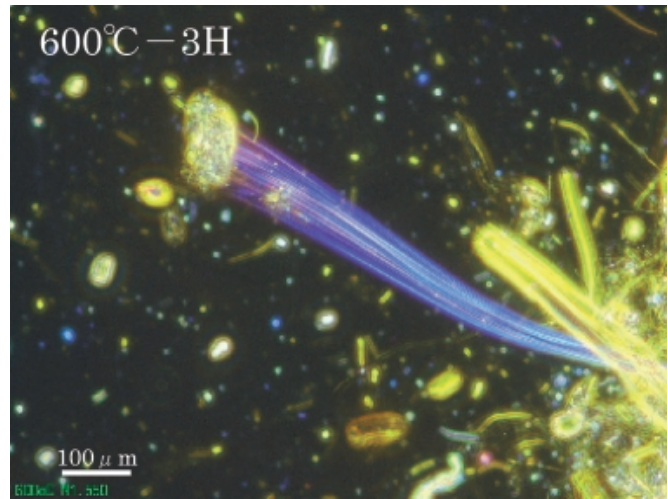

Fig. 3. Phase-contrast microscope photograph of chrysotile after heating at $600^{\circ} \mathrm{C}$ for $3 \mathrm{~h}$.

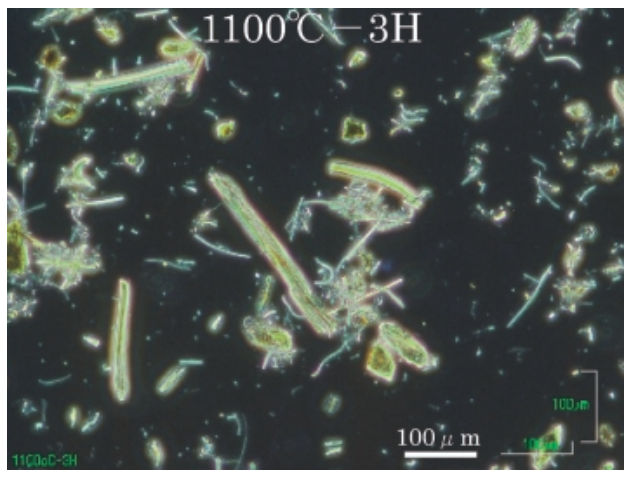

Fig. 5. Phase-contrast microscope photograph of chrysotile after heating at $1100^{\circ} \mathrm{C}$ for $3 \mathrm{~h}$.

Table 1. Counts of Fiber Chrysotile Particles in Sample after Heating at $600-1100^{\circ} \mathrm{C}$ for $3 \mathrm{~h}$. (This Counting Performed by Phase-Contrast Microscope in Reference to JIS A 1481: 2006.)

\begin{tabular}{|c|c|c|c|c|c|c|c|c|}
\hline & \multicolumn{2}{|c|}{ Slide 1 } & \multicolumn{2}{c|}{ Slide 2 } & \multicolumn{2}{c|}{ Slide 3 } & \multicolumn{2}{c|}{ Total } \\
\hline Temperature ("C) & Chrysotile & $\begin{array}{c}\text { Whole } \\
\text { number }\end{array}$ & Chrysotile & $\begin{array}{c}\text { Whole } \\
\text { number }\end{array}$ & Chrysotile & $\begin{array}{c}\text { Whole } \\
\text { number }\end{array}$ & Chrysotile & $\begin{array}{c}\text { Whole } \\
\text { number }\end{array}$ \\
\hline 600 & 23 & 1000 & 14 & 1000 & 23 & 1000 & 60 & 3000 \\
\hline 800 & 2 & 1000 & 2 & 1000 & 0 & 1000 & 4 & 3000 \\
\hline 900 & 1 & 1000 & 0 & 1000 & 4 & 1000 & 5 & 3000 \\
\hline 1000 & 0 & 1000 & 0 & 1000 & 0 & 1000 & 0 & 3000 \\
\hline 1100 & 0 & 1000 & 0 & 1000 & 0 & 1000 & 0 & 3000 \\
\hline
\end{tabular}

134438 [in Japanese].

6) Inoue, M. and Oda, K., Kokai-Tokkyo-Koho, Toku Kai Hei9110514 [in Japanese].

7) Hashimoto, S. and Yamaguchi, A., J. Ceram. Soc. Japan, Vol. 113, pp. 312-316 (2005) [in Japanese].

8) Stanton, M. F., Layard, M., Tegeris, A., Miller, E., May, M., Morgan, E. and Smith, A., J. Nat. Canc. Inst., Vol. 67, pp. 965-975 (1981).

9) Pott, F., IARC Sci. Publ., Vol. 30, pp. 261-272 (1980). 